
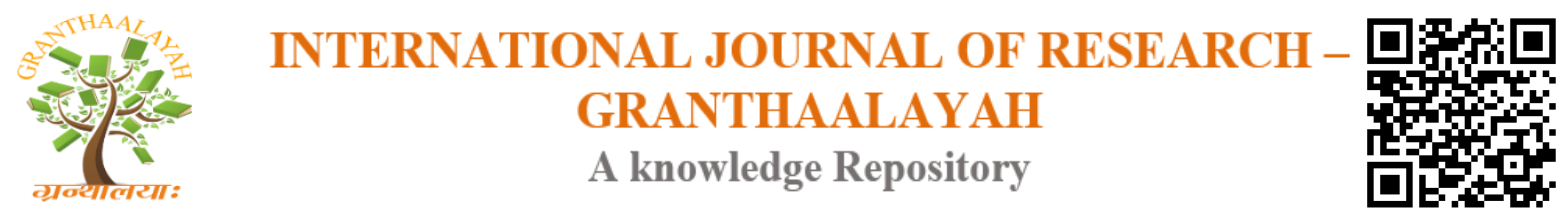

Management

\title{
ANALYSIS OF FOOD SECURITY STATUS AMONG RURAL FARMING HOUSEHOLDS IN MUBI NORTH LOCAL GOVERNMENT AREA OF ADAMAWA STATE, NIGERIA
}

\author{
A.S. Haddabi ${ }^{* 1}$, N. J Ndehfru ${ }^{1}$, A. Aliyu ${ }^{1}$ \\ ${ }^{1}$ Department of Agricultural Economics and Extension, Faculty of Agriculture Adamawa State \\ University, Mubi, Nigeria
}

\begin{abstract}
The study analyzes Food security status among rural farming households in Mubi North local Government Area of Adamawa state, Nigeria. Respondents' socio- economic characteristics, food security status determinants of household food security and production constraints faced by respondents in achieving food security in the study area were investigated. Data were collected from one hundred and twelve (112) randomly selected rural farmers in six villages of the six (6) selected wards of Mubi North local government area using structured questionnaire. The data were analyzed using descriptive statistics and binary logistic regression analysis. The result revealed that $72.32 \%$ of the respondents were male and $75 \%$ were married. Majority $(72.33 \%)$ of the respondents had one form of formal education or the other and with a mean farming experience of 12 years. The respondents were mostly in their economically active age (mean age of 37 years) and cultivate an average of 2.95 hectares of farm land using personal savings. The mean per capita food expenditure per month was estimated to be N6, 205.11 and the value was used as food security index, and majority (74.10\%) of the households were food secured in the study area. The result further revealed that educational level, farm size, farming experience and total monthly income of household heads were positively related to households' food security status, while age of households' head was inversely related to food security status. The major production constraints to achieving food security status in the study area include; poor access to credit facilities (98\%), high cost of agro-chemicals (81\%) inadequate and high cost of fertilizer (78\%), shortage of labour (77\%), poor storage facilities $(62 \%)$ and inadequate extension visit $(51 \%)$. The study among others recommended that rural farmers should be trained on farm management efficiency to boost production capacity and they should explore non-farm income to augment their existing income so as to increase their potentials considering that most of the farmers are youths.
\end{abstract}

Keywords: Food Security; Analysis; Status; Rural; Farming and Household.

Cite This Article: A.S. Haddabi, N. J Ndehfru, and A. Aliyu. (2019). "ANALYSIS OF FOOD SECURITY STATUS AMONG RURAL FARMING HOUSEHOLDS IN MUBI NORTH LOCAL GOVERNMENT AREA OF ADAMAWA STATE, NIGERIA.” International Journal of Research - Granthaalayah, 7(7), 226-246. 10.29121/granthaalayah.v7.i7.2019.757. 


\section{Introduction}

\subsection{Background of the Study}

Food security in a broad sense consists of having at all times an adequate level of basic food products to meet increasing consumption demand and mitigate fluctuations in output and prices. According to Maharjan and Chhetri (2006), food security is widely seen as access by all people at all times to enough food for an active life, while food insecurity is the inability of a household or individuals to meet the required consumption levels in the face of fluctuating production, price and income. At the national level, food security exists when all people at all times have the physical and economic access to sufficient, safe and nutritious food to meet their dietary needs and food preferences for active and healthy life, while at the household level, food security implies physical and economic access to food that is adequate in terms of quantity, safety and cultural accessibility, to meet each person's need (Ingawa, 2002).

It is a widely accepted fact that food is a basic necessity of life. Its importance at the household level is obvious since it is a basic means of sustenance. Adequate intake of quality food is a key requirement for healthy and Productive life. Helen (2002) asserted that food is useful for maintaining political stability, and insuring peace among people while food insecurity can result in poor health and reduced performance of children. Shala and Stacey (2001) found that many countries experienced food insecurity with food supplies being inadequate to maintain their citizens' per capita consumption. They also found that sub-Saharan Africa was the most vulnerable region. According to Shala and Stacey (2001), the average amount of food available per person per day in the region was 1,300 calories compared to the world wide average of 2,700 calories. Food and Agriculture Organization (2004) concluded that Africa has more countries with food insecurity problems than any other region.

According to Ingawa (2002), a country can be said to be enjoying food security when people's fear of not having enough to eat is removed and the most vulnerable group, namely women and children, in the marginal areas have access to adequate quality of food they want. According to the World Bank (1986), food security refers to access to food resources by each individual at all times for healthy and active life. Food demand in Nigeria has generally grown faster than either food production or total supply. Central Bank of Nigeria (2001) reported that the rate of increase in food production of 2.5 percent per annum does not keep pace with the annual Population growth rate of 2.8 percent per annum.

The issue of food security has been on the fore developmental sciences for many decades. Food security exists when all people at all times have physical and economic access to sufficient, safe and nutritious food that meet their dietary needs and food preferences for an active and healthy life (FAO,2006). There exist four major elements in accessing food security namely; availability, accessibility, utilization, quality and safety (Henneberry and Carrasco, 2014). While availability connotes the physical presence of a large quantity of food, utilization means sufficiency in both quantity of food and sustainability, implies access at all times and not losing such access (Omonona and Agoi, 2007). 
According to Henneberry and Carrasco (2014), food access, one of the key dimensions of food security, is a function of income and purchasing power of households. Food access is the ability of the households and nations to obtain the food needed to maintain nutritional balance. It encompasses physical access, economic access and sustainability access. Ayantoye et. al., (2011) stated that there is a connection between poverty levels in rural Nigeria and the level of food security, as well as its transition.

\subsection{Statement of the Problem}

Food is the basic need and necessity of life that must be satisfied before any other developmental issue. Inadequate nutrition is considered as measure of poverty in many societies or synonymous to poverty (Datt et. al., 2000). Helen (2002) noted that, food security maintains political stability, and ensures peaceful coexistence among people while food insecurity results in poor health and reduced performance of both children and adult. Food security is therefore defined "as a situation when all people, at all times, have physical and economic access to sufficient, safe and nutritious food to meet their dietary needs and food preferences for a healthy and active life" (FAO, 1996). Ironically, farming households are the most affected in terms of food insecurity and poverty in Africa especially the smallholder farming households though the rest of the population depends on their production. According to Cruz (2010) and Valdés et. al., (2010), majority (more than 80 percent) of the smallholder farmers in the world are food insecured and depends on land as their primary source of livelihoods. Three out of every four poor people live in rural areas and depend on agriculture either directly or indirectly for their Livelihood (World Bank, 2008).

In most parts of the world and especially in the developing countries, concerns regarding food security and its related issues are vital for poverty reduction. Attainment of food security is a core problem confronting farming households, especially women and rural populations due to low productivity in staple crop production, seasonal variability in food supply as well as price fluctuations. These problems facing farming households come about as a result of overreliance on rain-fed agriculture, none or inappropriate usage of chemical inputs as well as inadequate improved varieties of crops and animal species. Food security of farming households is of serious concern if Nigeria wants to consolidate her macroeconomic gains because; farmers who are vulnerable to food and nutritional insecurity have limited capacity to respond to agricultural programmes.

In Nigeria, the issue of food insecurity is of a major concern. This is particularly more in the northern Sudan Savannah and Sahel zones which have the highest prevalence of under nutrition (FAO, 1998). Fakiyesi (2001) also estimated that about $66 \%$ of Nigeria's populations live below poverty line as portrayed by their level of food security.

Fakiyesi (2001) also maintained that Nigeria's domestic food supply has been far short of the need of the population. This could result in reduced consumption among the poor. Consequently these categories of persons belong to the low - income groups and are therefore most vulnerable to food insecurity. Given the high cost of social services, nutritional level and food purchasing capacity tend to deteriorate as relatively large proportion of income goes to meeting these social services (Olayemi, 1998). 
Food production decisions are made mainly by small scale farmers who represent about $95 \%$ of the total food crop farming units in the country and produce about 90 percent $(90 \%)$ of the total food output. The apparent disparity between the rate of food production and demand for food in Nigeria has led to: (a) a food demand supply gap leading to a widening gap between domestic food supply and the total food requirement; (b) high rates of increase in food prices due to a growing food supply deficit despite food importation (Federal Ministry of Agriculture, FMA, 2008). And (c) an increase in the rate of food importation. It is against the above background, that this research was undertaken, because it becomes extremely important to analyze the households' food security among food crop farmers in Mubi North Local Government Area of Adamawa State, Nigeria.

\subsection{Research Questions}

The research was intended to provide answers to the following questions:

1) What are the socio-economic characteristics of the respondents?

2) What is the food security status of the respondents?

3) What are the determinants of household food security in the study area?

4) What are the production constraints faced by respondents in alleviating food insecurity in the study area?

\subsection{Objectives of the Study}

The main objective of the study was to analyze food security status of rural household farmers in Mubi North Local Government Area of Adamawa State.

The specific objectives were to:

1) describe the socio-economic characteristics of the respondents;

2) determine the food security status among the respondents;

3) examine the determinants of household food security among rural farming household;

4) identify the production constraints faced by respondents in achieving food security in the study area.

\subsection{Significance of the Study}

Nigeria's greatest challenge is that of feeding her teaming population. This is manifested with the continuous food crisis associated with short fall in supply, rising cost of living, poverty, malnutrition and diseases among others. By 1989, the total number of chronically hungry people was estimated at 550 million people (Adebayo, 2012). Food insecurity and hunger are forerunners to nutritional, health, human and economic development problem (Gebremedhin, 2000). Malnutrition affects one out of every three pre - school age children living in developing countries and children who are malnourished are less physically and intellectually productive as adults.

CBN (2004) report on the distribution and profile of poverty in Nigeria indicates that the rural areas are worse off, and that the propensity of a household falling below the poverty line is higher in the rural areas. The report also indicated that rural households are of low educational level and dovetails into low income. If this is to be averted a drastic step has to be taken to achieve a sustained growth in agricultural sector output. This study is therefore significant because it helped in providing solutions to some major problems of inadequate resource allocation and it also added to the existing study done in related field. 


\section{Literature Review}

\subsection{Food Security Status of Respondents}

According to Clement (2014) whose study result reveals that the incidence of food insecurity was high within the age bracket of 40-49 years (27.5\%) but the severity and depth was higher within the age bracket of 50 years and above. The age bracket within 40-49 years fell under potential food insecurity group with less than 50\% calorie deficiency, while those within the age bracket of 50 years and above fell within chronic food insecurity group with more than $50.0 \%$ calorie deficit. This agrees with the findings of FAO (2004) that about $4.7 \%$ of the population consumes less than their dietary requirements. This may be attributed to the old age which makes them less active, less productive and unable to look for jobs; as such, the severity is higher among this category. The incidence of food insecurity is also high among households in which the heads of family had low level of education (30.8\%); likewise, the depth and severity of food insecurity ( 0.3 and 0.29 , respectively), with the incidence being less among households headed by highly educated persons. This agrees with the findings of Amaza et. al., (2006), which suggests that the higher the educational level of a head of household, the more the food security status of the family.

The results also shows that the incidence, depth and severity were higher among families with large household size than among those with small household size. This is obvious because the larger the household size, the greater the responsibilities, especially, in a situation where many of the household members do not generate any income but only depend on the household head. This is in consonance with the findings of Maharjan and Chhetri (2006) that food secure households have small size and low dependency ratio.

According to Clement (2014) whose study result on the primary occupation of respondents reveals that the incidence of food insecurity was high among those who were involved in agro-processing (25.0\%) as their primary occupation compared to the dismal (6.7\%) among those involved in poultry keeping and $13.3 \%$ among those involved in crop farming as their primary occupation. However, the depth of food insecurity was higher among livestock keepers $(0.25)$ as against the dismal (0.10) among those involved in crop farming. Severity of food insecurity was also found to be higher among those involved in livestock keeping (0.34) and least among crop farmers (0.08). The depth and severity of food insecurity was found to be higher among those involved in livestock keeping.

According to Clement (2014) whose study result on the Income level of respondents reveals that households with income level of less than $(<\mathrm{N} 300)$ had the highest incidence, depth and severity of food insecurity status of $31.7 \%, 0.36$ and 0.41 , respectively, while the incidence in particular is less among households with income level greater than N901. This category also had the least depth (0.13). The implication of this finding is that accessibility to good food, in the volume to subdue hunger and taken in the right quality i.e. containing the correct nutritional requirement is low among a vast majority of the households. As such, nutrients-related diseases are likely to become rampant. Thus, consumption below the minimum level of calorie requirement indicates food insecurity condition. Helen (2002) opined that about 800 million people suffer from malnutrition and most of those under-nourished in low income countries like Nigeria. 


\subsection{Determinants of Food Security in Nigeria}

The different dimensions of food security from the definitions available are availability, accessibility, utilization, sustainability as well as safety (Omonona and Agoi, 2007; Ayantoye et. al., 2011; Jrad et. al., 2010; Food and Agriculture Organisation, World Food Programme and International Fund for Agricultural Development, 2012). All these studies have shown that access to food is a very important dimension of food security. Food security is determined by various socio-economic, natural and political factors. These include income, education, age, availability of infrastructure, availability of extension services, government policies on trade, agricultural land area under cultivation, and social safety net (Rose et. al., 1998; Mano et. al., 2003; Makombe et. al., 2010).

In Nigeria, determinants of food security are stability of access, household economic status, household income variability, quality of household human capital, degree of producer and consumer price variability, food storage and inventory, household size, and access to social capital (Olayemi, 1998; Amaza et. al., 2006; Oni et. al., 2011). Food security has also been found to be both temporal and spatial in nature (Ayantoye et. al., 2011; Devereux et. al., 2004). This definition integrates stability, access to food, availability of nutritionally adequate food and the biological utilization of food.

As a result, a synthesis of these definitions, with the main emphasis on availability, access, and utilization, serves as working definition in projects of international organizations. In the view of Babatunde et. al., (2007), among the developmental problems facing Nigeria, food security problem ranks topmost. Available statistics shows that the Nigeria food security picture is pathetic as more than 70 percent of the populace live in households too poor to have regular access to the food that they need for healthy and productive living (Aletor, 1999) ascribing Nigeria with highest incidence of food insecurity in Africa (FAO, 2005). In the analysis of Iremiren (1992), "Jesus taught us to pray for our daily bread among other requests in the family prayers".

For many years now, the price of the symbolic bread has gone beyond the reach of most Nigerians and it has disappeared from the breakfast menu. For few that still eat bread, it is "no more daily". Fasting in Nigeria has become the order of the day, not as a means of drawing nearer to God alone, but as a means of sustaining hope for another day's meal (Tewe, 1997). This statement is underpinned by the now universal $001 ; 101 ; 010 ; 110$ etc. menu formulae adopted not by students alone, but workers and indeed many households, whereby meals are skipped out of sheer necessity to ensure the availability of another days maintenance ration (Aletor, 1999).

\subsection{Causes of Food Insecurity in Nigeria}

According to Jacob (2013), food insecurity exists when people are undernourished as a result of the physical unavailability of food, their lack of social or economic access to adequate food. Food insecure people are those whose food intake falls below their minimum energy requirements as well as those who exhibit physical symptoms caused by energy and nutrient deficiencies resulting from an inadequate or unbalanced diet or from the body's inability to use food effectively because of infection or disease. 
According to FAO (2010) food insecurity refers to the consequences of inadequate consumption of nutritious food, considering the physiological use of food by the body as being within the domain of nutrition and health. Malnourishment also leads to poor health; hence individuals fail to provide food for their families. If left unaddressed, hunger sets in motion an array of outcomes that perpetuate malnutrition, reduce ability of adults to work and to give birth to healthy children and erode children's ability to learn and live productive, healthy and happy lives. This truncation of human development undermines a country's potential for economic development for generations to come.

Famine and hunger are both rooted in food insecurity. Food insecurity can be categorized as either chronic or transitory. Chronic food insecurity is a long time or persistent inability to meet minimum food consumption requirements while transitory food insecurity is a short-term or temporary food deficit. Chronic food insecurity translates into high degree of vulnerability to famine and hunger, ensuring food security presupposes the elimination of that vulnerability. While transitory food insecurity refers to changes in food security status - a sudden (often precipitous) decline in the ability to meet subsistence needs. Chronic insecurity is similar to undernourishment and is related to poverty existing mainly in poor countries. No problems can be solved unless its causes are known: therefore, knowing the causes of food insecurity will help us to locate the solutions. Discussing the causes of food insecurity in Nigeria is a very difficult task; this is because most Nigerians develop apathy towards locally produced food and prefer imported food which they consider as superior to domestically produced ones. The emergence of oil sector and the substantial revenue accruing from the sector shifted emphasis from agriculture to the extent that even domestic food production is not given the desired requirement. The government felt that it was better to import food than to embark on local production, especially when oil money has changed the tastes of most Nigerians in favor of foreign imported goods. The above reasons notwithstanding, according to Jacob (2013), are the causes of food insecurity in Nigeria.

\subsection{Problems of Food Security in Nigeria}

According to Jacob (2013) the first essential component of social and economic justice is adequate food production. Even if a nation cannot send cosmonauts to the moon, it should be able to feed her population, only then can it occupy place of pride in the committee of nations. Nigeria is a country richly blessed with abundant natural and human resources that if properly harnessed can feed its people and export the surpluses to other countries, yet it is experiencing persistent food crisis both in terms of quantity and quality. Cases of malnutrition and under nutrition are growing by the day. The food intake requirements of majority of Nigerians have fallen far below the international standard. Past effort at improving food supply through agricultural production has not yielded successful results. The programmes that were introduced only helped to alienate the peasant farmers who are the major producers of food in Nigeria. Some of the companies that had something to do with food production include:

1) The national Grains Production Company.

2) National Root Crops Production Companies.

3) North-east, Western and National Livestock Production Companies.

4) The Nigerian National Shrimp Company.

5) The Nigerian National Fish Company. 
Jacob (2013) maintained that these companies were set up by the federal Government in 1989 to participate in direct production of food. The major crops target includes maize, rice, millet, wheat, sorghum and cassava. One should mention in passing the establishment of 11 (eleven) River Basin Development Authorities, they were set up to develop river basins for meaningful agricultural production to make Nigeria self-sufficient in food production. Operation Feed the Nation (OFN) and Green Revolution were other short-lived national campaign launched to give agriculture a good image and to encourage land owners to take to farming not only as an occupation but also as a way of life. These programmes were more in favor of capital intensive and large scale commercial farmers who corruptly enriched themselves at the expense of poor peasant farmers.

\section{Methodology}

\subsection{Description of the Study Area}

Mubi North Local Government Area lies on Latitude $10^{\circ} 32^{\prime} \mathrm{N}$ to $10^{\circ} 11^{\prime} \mathrm{N}$ and Longitude $13^{\circ} 12^{\prime} \mathrm{E}$ to $13^{0} 35^{\prime} \mathrm{N}$. The area has a total land mass of $506.4 \mathrm{~km}^{2}$ and has a population size of 759,045 people. Mubi is the capital of Mubi North Local Government Area of Adamawa State in Nigeria. (Adebayo, 2004). Mubi North Local Government Area lies on the West bank of the Yedseram River, a stream that flows into Lake Chad and is situated on the Western flanks of the Mandara Mountain. It shares common boundaries with Borno State to the North, Hong Local Government Area to the West, Maiha Local Government Area to the South and Cameroon Republic to the East. (Adebayo, 2004).

Rainfall begins in April, progressing and reaching its peak in July / August and stops most of the time in October. Average annual rainfall ranges between $998 \mathrm{~mm}$ and $1262 \mathrm{~mm}$. Mubi North Local Government area consists of four districts namely; Mubi, Bahuli, Muchalla and Mayo - bani. (Adebayo, 2004). The major economic activities of the people are farming and trading. The major crops cultivated in the area are rice, sorghum, maize, cowpea, groundnut and sugar - cane. The ethnic groups are mainly; Fali, Gude, Marghi and Fulani.

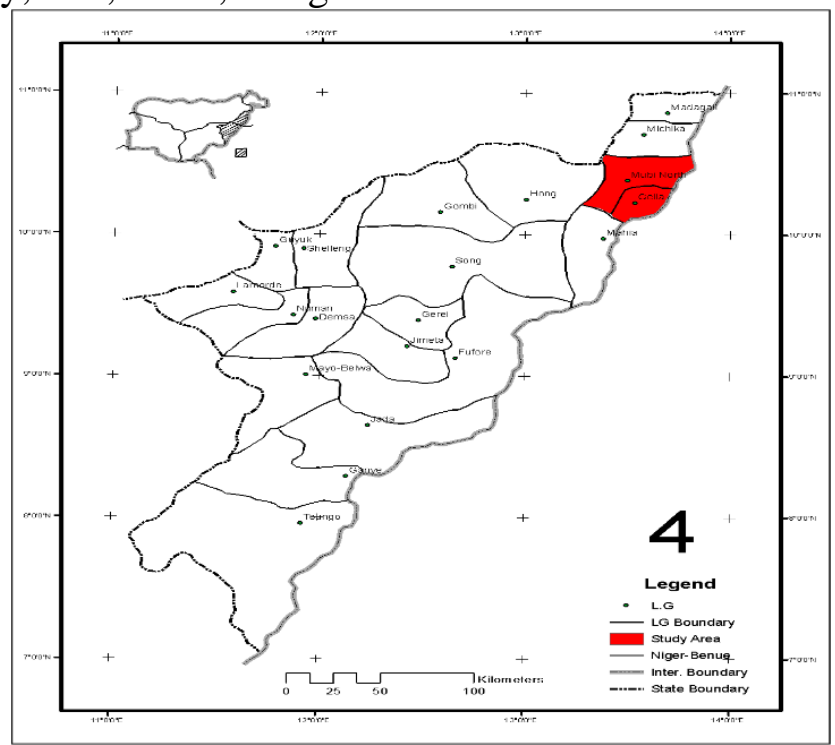

Figure 3.1: Map of Adamawa State Showing Mubi North Local Government Area Source: Google Map (2018) 


\subsection{Sampling Procedure}

The population of this study comprised the rural farming households of Mubi North Local government area. Sampling frame was prepared using purposive sampling of six (6) wards; including Kolere, Lokuwa, Digil, Mayo bani, Sabon Layi and Vimtim. A simple random sampling technique was employed to select 120 respondents. The researcher administered 120 questionnaires to 20 respondents each from each of the six wards mentioned above; to be used as the sample size for the study.

\subsection{Method of Data Collection}

Primary data was used for the study and was collected through the use of structured questionnaires administered to household heads in 6 Villages of the 6 wards selected for the study. The questions were structured to elicit answers on the objectives of the study.

\subsection{Method of Data Analysis}

Descriptive statistics such as means, percentages and frequency tables was employed to describe the socio - economic characteristics of the farming households in the study area. It is expressed as;

$\mathrm{X}=\sum \frac{f x}{n}$

Where $\mathrm{X}=$ mean, $\sum f x=$ sum of individual observation and $\mathrm{n}=$ sample size

Food security index estimation, using expenditure method as used by Omonona and Agoi (2007) and Zubairu and Maurice (2014) was used to classify the respondents into food secure and food insecure households in a bid to establishing the food security status of the individual households. It is given by;

$\mathrm{F}_{1}=\frac{\text { per capita food expenditure for the ith household }}{\frac{2}{3} \text { mean per capita food expenditure of all households }}$

Where

$\mathrm{Fi}=$ food security index

When Fi $>1$ = food secure ith household.

$\mathrm{Fi}<1=$ food insecure ith household.

A food secure household is therefore that whose per capita monthly food expenditure fell above or is equal to two-third of the mean per capita food expenditure. On the other hand, a food insecure household is that whose per capita food expenditure food expenditure fell below two-third of the mean monthly per capita food expenditure. 


\subsubsection{Empirical Model for the Determinants of Food Security}

A binary logit regression model as used by Omotesho et. al., (2006) and Oyebanjo et. al., (2013). Was used to examine the determinants of household food security in the study area, the logistic model is specified explicitly as:

$\mathrm{Fi}=b_{0}+b_{1} X_{1}+b_{2} X_{2}+b_{3} X_{3}+b_{4} X_{4}+b_{5} X_{5}+b_{6} X_{6}+b_{7} X_{7}+b_{8} X_{8}+b_{9} X_{9}+b_{10} X_{10}+b_{11} X_{11}+$

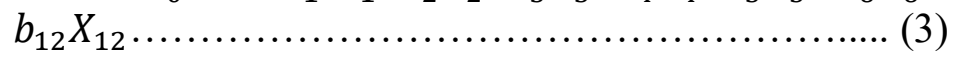

Where

$\mathrm{Fi}=$ Food security status (Dummy where 1, if household head is food secure; and 0, if household head is food insecure)

$X_{1}=$ Age of household head (years)

$X_{2}=$ Level of education of household head (measured by years spent in school)

$X_{3}=$ Farm size (hectares)

$X_{4}=$ Farming experience (years)

$X_{5}=$ Household size (measured by number of persons in a household)

$X_{6}=$ Credit access (dummy, where $1=$ credit access and $0=$ otherwise)

$X_{7}=$ Gender $($ Male $=1$, Female $=2$ )

$X_{8}=$ Primary occupation (dummy, where $1=$ farming access and $0=$ otherwise)

$X_{9}=$ Monthly income ( $)$

$X_{10}=$ Marital Status (dummy, where $1=$ if married, and $0=$ otherwise.)

$X_{11}=$ Source of Labour (man- day)

$X_{12}=$ Farm output $(\mathrm{Kg})$

\section{Results and Discussions}

\subsection{Socio-economic Characteristics of the Respondents}

The socioeconomic characteristics is an economic measure of persons' economic and social position relative to age, sex, marital status, household size, educational background, farming experience, farm size, primary occupation, among others (Mutisya et. al., 2015).

The socioeconomic characteristics of the respondents is presented in table 4.1. The table revealed the demographic traits including Age, Gender, marital status etc of the respondents. It indicated that $24.10 \%$ of the respondents were between 20 and 29 years of age, while $31.25 \%$ were within the age range of $30-39$ years, those that were within the age of $40-49$ years are $35.71 \%$, $50-$ 59 years and 60 years accounted for $7.14 \%$ and $1.78 \%$ respectively. The mean age of the respondents is 37.63 years, an indication that the respondents are still very active to engage in agricultural production that will contribute towards household food security. The result is in line with the findings of Dercon and Krishnan (1996) and Yusuf et. al., (2015) who claimed that at the active working age, household heads adopts innovations that positively affect their productivity and income.

The table also revealed the gender distribution of the respondents that $72.32 \%$ of the respondents were male, while female constituted $27.67 \%$. The result shows that both male and female were 
involved in crop farming but it is mostly undertaken by the male gender, thus agreeing with the finding of Ndaghu et. al., (2009) and Robert et. al., (2013) who reported that males are the most household heads and they are responsible for major production decision. This finding however disagrees with Zubairu and Maurice (2014) and Hadebe and Mpofu (2013) who found that women are mostly involved in food crop production which ensures food security. The study shows that majority $(75.00 \%)$ of the respondents were married, while $9.8 \%$ were single, divorced and widows accounted for $4.46 \%$ and $10.71 \%$ respectively. This explains the significance of farming labour to agricultural production in a typical or normal rural community in Nigeria. Households where the respondents are married and both the spouses are working are expected to be more food secured than single households, widowed or divorced. Most rural farmers will prefer to marry in order to have cheap labour for agricultural activities to enable their household to be food secured (Kirwan and Maye, 2013). The distribution of the respondents by household size shows that most (87.49\%) of the respondents have household sizes of $1-9$ persons, while about $12.40 \%$ have household size of 10 persons and above. The mean household size is about 6 persons. Larger household size can serve as source of family labour even though dependency ratio will be high. Larger household size tends to reduce per capita food expenditure of the household, thus increasing their likelihood of being food insecured. Adebayo (2012) supported this assertion that the larger the family size the lesser the food availability to each person within the household and also nutritional status will be affected.

The educational distribution of the respondent in the table reveals that $27.67 \%$ of the respondents did not have any form of education. In essence, the majority (72.31\%) had one form of formal education or the other. The result shows that majority of the respondents were literate and this can enhance their food security status. The level of education of household head is an important factor to improved farm production and management techniques. It also determines income earning capacity and food expenditure. Agreeing with Adebayo (2012) and Akarue and Bakporhe (2013) who opined that literate status can improve food security status and also the adoption of improved farm practices. Educated farmers adopt agricultural innovations easier, and this could improve their agricultural productivity and ensure food security.

The occupational distribution of respondents as presented in the table indicates that $44.64 \%$ of the respondents had farming as their primary occupation, $26.78 \%$ were civil servants and $22.32 \%$ were traders, while artisans constituted $6.25 \%$ of the respondents. It is clear that agricultural sector is the highest employer of labour in the study area. The result is in agreement with the study carried out by Shehu et. al., (2012) who found out that farming constituted the major occupation of people in the rural areas in Nigeria.

The distribution of the respondents according to farm size is presented in the table shows that $92.85 \%$ of the respondents had farm size of 1-5 hectares, while only $7.14 \%$ had farm size of 6 hectares and above. The mean farm size of the respondents is about 2.95 hectares. The finding revealed that food crop farmers in the study area are mainly small scale farmers, hence food production is at subsistence level which could lead to diversification of income sources by farmers to be food secured. This finding corroborates with the finding of Arene and Anyaeji (2010) and Oyebanjo et. al., (2013) that majority of Nigerian farmers are small scale farmers who cultivate less than 5 hectares. 
The distribution of the respondents by farming reveals that $51.78 \%$ of the respondents had $1-10$ years farming experience, $32.14 \%$ had $11-20$ years farming experience, while $16.07 \%$ had farming experience of 21 years and above. The mean farming experience is about 12.28 years. This implies that most of the farmers in the study area were well experienced in food crop production. This is in consonance with the finding by Zubairu and Maurice (2014) who reported that farmers with more years of experience in farming are likely to adopt new innovations easier that would improve their productivity and ensure food security.

Land is an important factor of production which helps in the production of goods and services. The mode of land acquisition could determine the scale of farm operation undertaken by the farmers. Jayne et. al., (2005) noted that access to land is a key factor in reducing rural poverty and ensure food security. The distribution of respondents by mode of land acquisition is presented in table 4.9 below. The result reveals that most (51.78\%) of the respondents used inherited farm lands, (33.93\%) used rented farm lands while $11.60 \%$ and $2.67 \%$ used purchased and community farm land respectively.

The distribution of the respondents on the basis of access to credit facilities revealed that most (78.57\%) of the respondents had no access to credit facility, while $21.42 \%$ had access to credit facility. Access to credit is an important factor that can influence the likelihood of adoption of new technologies by food crop farmers to attain food security. Farm credit is widely recognized as one of the intermediating factors between adoptions of farm technologies and increase in farm income among rural farmers in Nigeria (Akpan et. al., 2013); hence food crop farmers in the study area may lack the ability to expand their production activities due to limitation to finance.

Agricultural finance is an effective instrument for improving agricultural productivity and encourage food production. The table revealed that majority $(75.89 \%)$ of the respondents utilized personal savings to finance their agricultural production, $18.75 \%$ respondents finance their food production through friends and families, while $3.57 \%$ and $1.78 \%$ received support through loan and bank and cooperatives association respectively. The over-dependence on personal savings by respondents to finance agricultural production might be attributed to poor access to agricultural credit which is responsible for their involvement in small scale production and is a characteristics feature of peasant agriculture (Ajagbe, 2012).

Food security index estimation, using expenditure method as used by Omonona et. al., (2007) and Zubairu and Maurice (2014) were employed to classify the respondents into food secure and food insecure household in order to establish the food security status of the individual households. A food secure household is therefore, that whose per capita monthly food expenditure is at least twothird of the mean per capita monthly food expenditure. On the other hand, a food insecure household is that whose per capita monthly expenditure is less than two-third of the mean monthly per capita food expenditure. The mean per capita food expenditure per month was estimated to be N6, 205.11 and this value was used as food security index. That is, any respondent whose per capita weekly mean food expenditure is less than N6, 205.11(Food security index) was regarded as being food insecure. The distribution of the respondents by food security status in Table 4.12 reveals that majority $(74.10 \%)$ of the respondents were food secured, while $25.89 \%$ were food insecure. Similar results were obtained by Oyebanjo et. al., (2013) and Zubairu and Maurice 
(2014). However, Agwu and Oteh (2014) who found out that majority of households in Abia State, Nigeria were food insecure.

Socio-economic characteristics of the respondents

\begin{tabular}{|l|l|l|}
\hline Characteristics & Frequency & Percentage (\%) \\
\hline Age Range (yrs) & & \\
$20-29$ & 27 & 24.10 \\
\hline $30-39$ & 35 & 31.25 \\
\hline $40-49$ & 40 & 35.71 \\
\hline $50-59$ & 8 & 7.14 \\
\hline$>60$ & 2 & 1.78 \\
\hline Gender & Frequency & Percentage (\%) \\
\hline Male & 81 & 72.32 \\
\hline Female & 31 & 27.67 \\
\hline Marital status & Frequency & Percentage (\%) \\
\hline Single & 11 & 9.82 \\
\hline Married & 84 & 75.00 \\
\hline Divorced & 5 & 4.47 \\
\hline Widow & 12 & 10.71 \\
\hline Household size & Frequency & Percentage (\%) \\
\hline $1-4$ & 41 & 36.60 \\
\hline $5-9$ & 57 & 50.89 \\
\hline $10-14$ & 10 & 8.92 \\
\hline$>15$ & 4 & 3.57 \\
\hline Educational level & Frequency & Percentage (\%) \\
\hline Non formal education & 31 & 27.67 \\
\hline Primary education & 25 & 22.32 \\
\hline Secondary education & 41 & 36.60 \\
\hline Tertiary education & 15 & 13.39 \\
\hline Main occupation & Frequency & Percentage (\%) \\
\hline Farming & 50 & 44.64 \\
\hline Civil servants & 30 & 26.78 \\
\hline Trading & 25 & 22.32 \\
\hline Artisan & 7 & 6.25 \\
\hline Farm size & Frequency & Percentage (\%) \\
\hline$<1$ & 18 & 16.07 \\
\hline $1-5$ & 86 & 76.78 \\
\hline $6-1$ & 8 & 7.14 \\
\hline Farming experience & Frequency & Percentage (\%) \\
\hline $1-10$ & 58 & 51.78 \\
\hline $11-20$ & 36 & 32.14 \\
\hline $21-30$ & 14 & 12.50 \\
\hline $31-40$ & 4 & 3.57 \\
\hline Type of land ownership & Frequency & Percentage (\%) \\
\hline Purchase & 13 & 11.60 \\
\hline & & \\
\hline & & \\
\hline
\end{tabular}




\begin{tabular}{|l|l|l|}
\hline Rent & 38 & 33.92 \\
\hline Community & 3 & 2.67 \\
\hline Inheritance & 58 & 51.78 \\
\hline Access to credit & Frequency & Percentage (\%) \\
\hline Yes & 24 & 21.42 \\
\hline No & 88 & 78.57 \\
\hline Sources of finance & Frequency & Percentage (\%) \\
\hline Personal saving & 85 & 75.89 \\
\hline Loan from bank & 4 & 3.57 \\
\hline Friends and relatives & 21 & 18.75 \\
\hline Cooperatives associations & 1 & 1.78 \\
\hline Food Security Status & Frequency & Percentage (\%) \\
\hline Food secure & 83 & 74.10 \\
\hline $\begin{array}{l}\text { Food insecure } \\
\text { Food Security index }=6,205.11\end{array}$ & 29 & 25.89 \\
\hline Total & 112 & 100 \\
\hline
\end{tabular}

Source: Field Survey, 2018

\subsection{Determinant of Household's Food Security}

The factor influencing food security among farming households in the area were analyzed using binary logistic model and the result presented in Table 4.13. The result shows that age, education, farm size, farming experience, gender, source of labor and monthly income were significant factors influencing food security status of farming households in the study area.

The finding reveals that the coefficient of age $\left(\mathrm{X}_{1}\right)$ is negative and significant at $5 \%$ level. This implies that as respondents' age increase the likelihood of being food secured decrease. Young and energetic household heads are expected to cultivate larger farms compared to the older and weaker household heads. Also, older household heads may not have the ability to obtain off-farm jobs and income which younger household heads can. This is agreeing with Oluwatayo (2012) who identified age as a major determinant of food security among households.

The result shows that education level $\left(\mathrm{X}_{2}\right)$ has a positive coefficient and is significant at $10 \%$ level. This implies that increase in years of formal education level increases the likelihood of household to be food secured. Education affords people opportunity to secure white collar and well-paid jobs that increase their income level. Lower educational level impedes access to better job opportunities in the labour market and also hampers more profitable entrepreneurship (FAO, 2012). Food insecurity incidence decreases with increase in level of education (Omonona et. al., 2007).

The result also revealed that farm size is an important factor that influences food security status of households. The coefficient of farm size is positive and statistically significant at 5\% level implying that the larger the farm size of the household, the higher the expected level of production. It is therefore expected of a household with more farm size to be more food secured than a household with smaller farm size. The result is in consonance with Okon et. al., (2017) who reported that there is hope for increasing output by expanding farmland. 
Farming experience refers to the number of years household heads are engaged in farming. The coefficient of farming experience is positive and statistically significant at $10 \%$ level. An experienced household head is expected to have more insight and ability to diversify his production to minimize risks of food shortage. Also, an experienced farmer is expected to have adequate knowledge in pests and diseases management as well as good knowledge of weather. This agrees with the findings of Feleke et. al., (2003) and Oluyole et. al., (2009) who found a positive relationship between farming experience and food security status.

Monthly income $\left(\mathrm{X}_{9}\right)$ has positive coefficient and statistically significant at 5\%. Income of households has positive effect on food security status implying that the more gainfully employed a household head is, and he earns income the greater the chances of being food secure. The income is expected to increase households' production and access to more quantity and quality food. This agrees with Okwoche et. al., (2012) who reported that an increase in income increases the likelihood of households being food secured.

Table 4.2: Summary Result of Logistic Regression Analysis

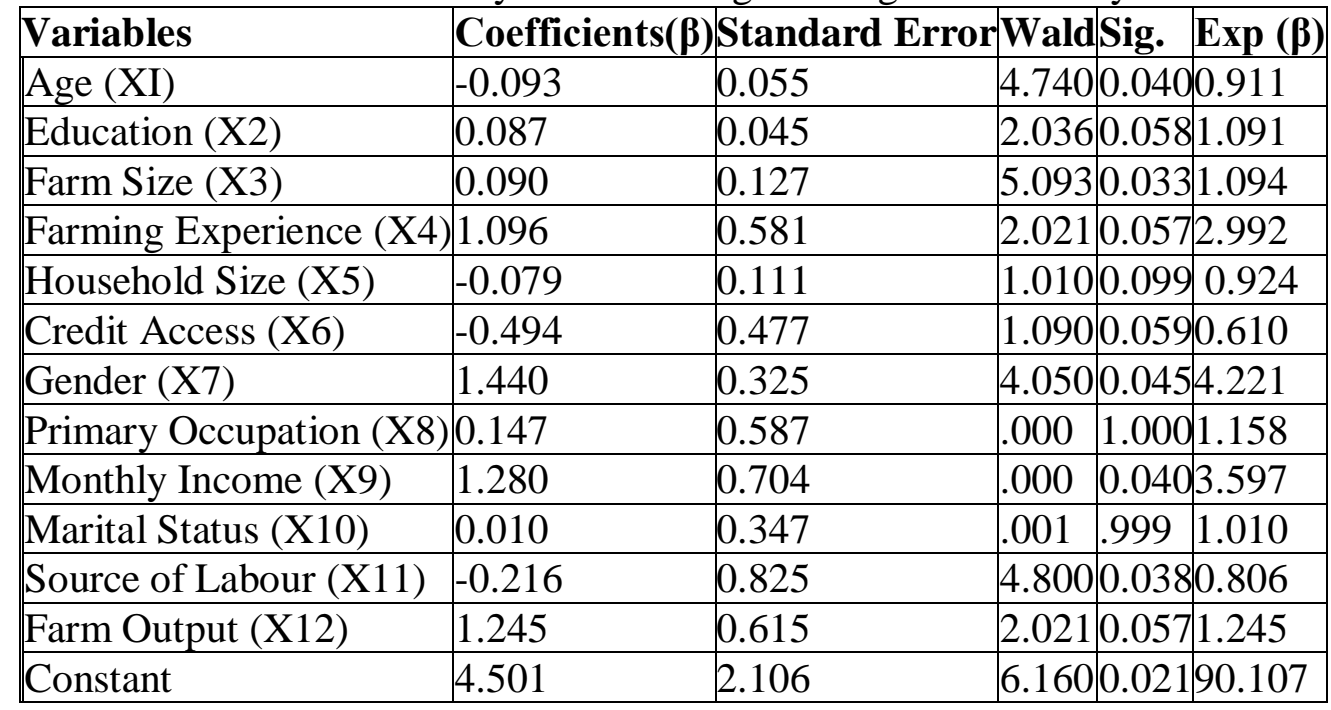

Source: Computer Output from SPSS Version 20

*Significant at $10 \%$ level, **Significant at $5 \%$ level

\subsection{Constraints to Food Crop Production in the Study Area}

The distribution of the respondents based on constraints faced by food crop farmers in the study area is presented in Table 4.14. The result reveals that the most severe problems affecting food crop farmers are poor access to credit facilities (87.50\%), high cost of agrochemicals (72.32\%) and inadequate $\&$ high cost of fertilizer $(69.64 \%)$ where they are ranked $1^{\text {st }}, 2^{\text {nd }}$ and $3^{\text {rd }}$ respectively in order of severity. Others include; shortage of labour $(68.75 \%)$, poor storage facilities $(55.35 \%)$, and inadequate extension contacts $(45.53 \%)$, and these are ranked $4^{\text {th }}, 5^{\text {th }}$ and $6^{\text {th }}$ respectively in order of severity. From the analysis it is evident that most of the constraints are serious as they affect a greater proportion of all the respondents. These problems may partly be responsible for the small size of farm lands cultivated by the farmers (Adebayo, 2012). 
Table 4.3: Distribution of Respondents Based on Production Constraints to ensure Food Security

\begin{tabular}{|l|c|l|l|}
\hline Constraints & Frequency* & Percentage (\%) & Ranking \\
\hline Poor access to credit facilities & 98 & 87.50 & 1 \\
\hline High cost of agrochemicals & 81 & 72.32 & 2 \\
\hline Inadequate \& high cost of fertilizer & 78 & 69.64 & 3 \\
\hline Inadequate extension visit & 51 & 45.53 & 6 \\
\hline Shortage of labour & 77 & 68.75 & 4 \\
\hline Drought/Flooding & 20 & 17.85 & 9 \\
\hline Pests and diseases & 42 & 37.50 & 7 \\
\hline High cost of transportation & 32 & 28.57 & 8 \\
\hline Poor storage facilities & 62 & 55.35 & 5 \\
\hline
\end{tabular}

Source: Field Survey, 2018

*Multiple responses

\section{Summary, Conclusions and Recommendations}

\subsection{Summary}

The study analyzed the food security status of rural households in Mubi North Local Government Area of Adamawa State, Nigeria. The specific objectives were to describe the socio economic characteristics of rural farmers, determine their food security status, and examine the determinants of household food security among rural farming households and identify the production constraints faced by the respondents in achieving food security in the study area. Data were collected from 112 randomly selected rural farmers in six villages from six wards in Mubi North Local Government Area using structured questionnaires. The data were analyzed using descriptive statistics involving the use of frequency distribution tables, percentages and inferential statistics involving the use of logit regression model.

The result revealed that $72.32 \%$ of the respondents were male and $75 \%$ were married majority $(72.33 \%)$ of the respondents had attained a level of formal education and with a mean farming experience of 12 years. The respondents were mostly in their economically active age (mean age of 37 years) and cultivate an average of 2.95 hectares of farm land using personal savings. The mean per capita food expenditure per month was estimated to be $\$ 6,205.11$ and the value was used as food security index, and majority (65.17\%) of the household were food secured in the study area.

The result further revealed that educational level, farm size, farming experience and total monthly income of household head were positively related to household's food security status; while age of household head was inversely related to food security status. The major production constraints to achieving food security status in the study area include; poor access to credit facilities, high cost of agro-chemicals, inadequate and high cost of fertilizer, poor storage facilities and inadequate extension contacts. Other constraints include shortage of labour, pests and diseases and high cost of transportation. 


\subsection{Conclusions}

Based on the study result, the following conclusions were made; crop production in the study area is mostly undertaken by male farmers who are in their prime age. They are mostly small scale farmers. Majority of rural farmers in the area are food secured with poor access to credit facilities as their greatest concern.

\subsection{Recommendations}

Based on the findings of this research, the following recommendations are drawn or proffered.

1) There should be easy access to credit facilities in order to empower farming households to increase their scale of production capacity.

2) Farming households should be educated on essential farm management practices so that they can be able to raise their production potential within the limited available resources.

3) There is the need for farmers to explore other non-farm income generating activities that can subsequently enhance food security.

4) Women and family labour should be encouraged to reduce the problem of high cost of labour.

\section{References}

[1] Adebayo, A. A. (2004). Mubi Region. A Geographic Synthesis. Paraclete Publishers. Yola. Pp. 1737.

[2] Adebayo, O.O. (2012). Effects of Family Size on Household Food Security in Nigeria. Asian Journal of Agriculture and Rural Development. 2 (2), 136-141.

[3] Agwu, N.M. and Oteh, O.U. (2014). Analysis of Income Inequalities and Food Security among Farmers in Abia State, South Eastern Nigeria. Management, Economic Engineering in Agriculture and Rural Development. Vol. 14 issue 3, p7-13.

[4] Ajagbe, F.A. (2012). Analysis of Access to and Demand for Credit by Small Scale Entrepreneurs. Evidence from Oyo State, Nigeria. Journal of Emerging Trends in Economics and Management Sciences. Volume 3 (3): 180-183.

[5] Akarue, O.B. and Bakporhe, O.T. (2013). Food Insecurity and its Determinants In Rural Households in Ughelli North Local Government Area of Delta State. Nigeria. Department of Agricultural Science Education, College of Education, Warri, Nigeria. International Journal of Innovative Agriculture and Biology Research 1 (2): 20-30, 2013. Seath Publications, 2013, ISSN: 2354-2934.

[6] Akpan, S.B., Jeiyol, E.N., and Tee, T.N. (2013). Gender Analysis of Access to Credit by Rural Small Scale Farmers in Benue State Nigeria. American International Journal of Social Science. Vol. 2. No. 6. August 2013.

[7] Aletor, V.A. (1999. Anti-nutritional Factors as Nature's Paradox in Food and Nutrition Securities. Inaugural Lecture Series 15. Federal University of Technology. Akure. 12th August, 1999. Pp. 188.

[8] Ali, D. (1994). Executive Summary and Introduction: Food and Food Security In Africa. Food and Agricultural Organization of the United Nations. Rome. Italy.

[9] Amaza, P.S., Umeh, J.C., Hesen, J. and Adejobi, A.O. (2006). Determinants and Measurement of Food Insecurity in Nigeria: Some Empirical Policy Guide. Paper Presented at the International Association of Agricultural Economists' Conference, Gold Coast, Australia, and August 12-26.

[10] Anyanwu, A. C., Agwu, A. E., and Musa, A. P. (2001). Adoption of Gender Specific Innovation by Women in State. Journal of Agricultural Extension 5, 64-72. 
[11] Arene, C.J., and Anyaeji. J.(2010). Determinants of Food Security Among Households in Nsukka Metropolis of Enugu State. Nigeria. Pakistan Journal of Social Sciences 30 (1): 9 - 16.

[12] Ayantoye, K., Yusuf, S.A., Omonona, B.T., and Amao, J.O. (2011). Food Insecurity Dynamics and its Correlates among Rural Households in South Western Nigeria. International Journal of Agricultural Economics and Rural Development 4(1): 43-55.

[13] Babatunde, R.O., Omotesho, O.A., and Sholotan, O.S. (2007). Socio-Economic Characteristics and Food Security Status of Farming Households in Kwara State, North-Central Nigeria. Pakistan Journal of Nutrition 6(1): 49-59.

[14] Bzugu, P.M., Gwary, M.M., and Idrisa, Y. (2005). Impact of Extension Services On Rural Poverty Alleviation among Farmers in Askira Uba Local Government Area, Borno State. Sahela Analyst, 7(1\&2), 94-102.

[15] Central Bank of Nigeria (2001). Economic and Financial Review vol. 36 No. 1.

[16] Central Bank of Nigeria (2004). Central Bank of Nigeria Annual Report and Financial Statements.

[17] Clement, A.C. (2014). Assessment of Food Security Status among Rural Farming Households in Guma Local Government Area of Benue State. Nigeria. Economic Policy Research Department Nigerian Institute of Social and Economic Research (NISER) Ibadan, Oyo State.

[18] Clover, J. (2003). Food Security in Sub-Saharan African. African Security Review 12(1).

[19] Cruz, L. (2010). Responsible Governance of Land Tenure: An Essential Factor For the Realization of the Right to Food. Land Tenure Working Group Discussion Paper 15, FAO. Rome.

[20] Datt, G., Simler, K., Mukherjee, S., and Dava, G. (2000). Determinants of Poverty in Mozambique 199677 (FCND Discussion Paper. No. 78). International Food Policy Research Institute. Washington, DC.

[21] Dercon, S., and Krishnan, P. (1996). Income Portfolio in Rural Ethiopia and Tanzania: Choices and Constraints. Journal of Development Studies. 32 (6): 850-75.

[22] Devereux, S., Baulch, B.B., Hussein, K., Shohan, J., Sida, H., and Wilcock, D. (2004). Improving the Analysis of Food Insecurity: Food Insecurity Measurement, Livelihoods Approaches and Policy: Applications in Food Insecurity Vulnerability and Mapping System. Environmental Science Policy. (7): Pp. 487-498.

[23] Duhaime, G., and Godmaire, A. (2002). the Conditions of Sustainable Food Security. An (Ed). Sustainable Food Security in the Arctic. State of Knowledge. Edmonton, University of Alberta, CCI Press and GETIC Occasional Publications Series No. 52. Pp. 15 - 45.

[24] Fakiyesi, O. M. (2001). Encouraging Growth to reduce Poverty in Nigeria. In C.B.N. Economic and Financial Review vol. 39 No. 2. Pp.132-137.

[25] Food and Agriculture Organization (1996). Food and Agriculture Organization. World Food Summit, November 13-17, 1996, Rome, Italy. Technical Background Documents, 6-13, Vol II. Pp1-47.

[26] Food and Agriculture Organization (1998). Food and Agricultural Organization of the United Nations. Energy for sustainable Development and Food Security in Africa. Food and Agricultural Organization of the United Nations, Rome, Italy.

[27] Food and Agriculture Organization (2002). The State of Food Insecurity in the World. 2002. Rome. Pp.4-10.

[28] Food and Agriculture Organization (2004). Food and Agricultural Organization of the United Nations. The State of Food Insecurity in the World: Monitoring progress toward the world food summit and Millenium Development Goals. Rome, F.A.O.

[29] Food and Agriculture Organization (2005). Food and Agricultural Organization of the United Nations. FAOSTAT, Statistical Database. Rome, FAO.

[30] Food and Agriculture Organization (2006). the State of Food Insecurity in The World. Food and Agriculture Organization of the United Nations. Viale delle Terme di Caracalla, 00153 Rome, Italy.

[31] Food and Agriculture Organization (2010). Global Hunger Declining but Still Unacceptably High: International Hunger Targets Difficult to Reach. Economic and Social Development Department September 2010. Rome: FAO. 
[32] Food and Agriculture Organisation, World Food Programme and International Fund for Agricultural Development (2012). The State of Food Insecurity in the World 2012: Economic Growth is necessary but not sufficient to Accelerate Reduction of Hunger and Malnutrition. Rome, FAO.

[33] Food and Agriculture Organisation (2012). The State of Food Insecurity in The World 2012: Economic Growth is Necessary but not sufficient to Accelerate Reduction of Hunger and Malnutrition. FAO Inter- Departmental Working Group, Rome. Italy. ISBN- 13:9789251073162, Pages: 60.

[34] Feleke, S.T., Kilmer, R.L., and Gladwin, C.H. (2003). Determinants of Food Security in Southern Ethiopia at the Household Level. Agricultural Economics 33 (3): 351-363.

[35] Fayeye, T.R. and Ola, D.J. (2007). Strategies for Food Security and Health Africa. World Journal of Agricultural Sciences. Vol. 3. No. 6. Pp. 808-814.

[36] Federal Government of Nigeria (2007). Federal Republic of Nigeria Official Gazette: Legal Notice on Publication of the Details of the Breakdown of the National and State Totals of the 2006 Census.

[37] Federal Ministry of Agriculture (2008). Food Consumption: Food and Nutrition Paper 20. FAO. Rome.

[38] Frankenberger, T., and Mc Caston, M. (1999). Rapid Food and Livelihood Security Assessments: A Comprehensive Approach for Diagnosing Nutritional Security. Overcoming Malnutrition in Developing Countries, Overseas Publishers Association. Amsterdam.

[39] Gebremedhin, T.G. (2000) Problems and Prospects of the World Food Situation. Journal of Agribusiness. 18 (2) 221-236.

[40] Global Hunger Index Report (2012). the Challenge of Hunger: Ensuring Sustainable Food Security under Land, Water and Energy stresses. IFPRI, Concern Worldwide, Welthungerhilfe and Green Scenery: Bonn / Washington, DC / Dublin October 2012.

[41] Google Map. (2018). Map of Adamawa State Showing Mubi North Local Government Area. Retrieved from https://www.google.com/imgres?Imgurl=http\%3A\%2F\%2Farticle. sapub.org\%2Fimage\%2F10.5923.j.Geo.20150501.03_001.gif\&imgrefurl=http\%3A\%2F\%2Farticle.s apub.org\%2F10.5923.j.geo.20150501.03.html\&docid=yrJ3rso7ldtb_M\&tbnid=ENrPiP8f3XP8P M\%3A\&vet=10ahUKEwimOKXBmeHZAhXCK8AKHfanA2gQMwgQMwgzKAMwAw..i\&w= 1099\&h=1345\&bih=659\&biw=1366\&q=adamawa\%20state\%20map\%20showing\%20mubi\%20n orth\&ved=OahUKEwimOKXBmeHZAhXCK8AKHfanA2gQMwgzKAMwAw\&iact=mrc\&uact $=8$

[42] Hadebe, L.B., and Mpofu, J. (2013). Empowering Women through Improved Food Security in Urban Centers. A Gender Survey in Bulawayo Urban Agriculture. African Educational Research Journal. 1 (1): 18-32.

[43] Helen, H. J. (2002): Food Insecurity and the food stamp Programme. American Journal of Agricultural Economics. Vol. 84 No. 5 Pp. 1215 - 1218.

[44] Henneberry, S., and Carrasco, D. (2014). Global Food Security: Emerging Economics and Diverging Food Markets. Journal of Food Distribution Research 45(1).

[45] Ibeanu, O. (2009). Policy Guidelines on Crop Production and Agro-based Industrialization in Nigeria, Agricultural Development Bulletin. Abuja.

[46] Idrisa, Y.L., Gwary, M.M., and Ibrahim, A. (2006): Determinants of Adoption of Cassava Farming Technologies in Mubi north Local Government Area of Adamawa State Nigeria. Journal of Production Agriculture and Technology, 2(2): 26-36.

[47] International Journal of Research in Humanities and Social Studies (2014). Volume 1, Issue 2, December 2014. Pp. 34-42. ISSN 2394-6288 (Print) And ISSN 2394-6296 (Online).

[48] Ingawa, S. A. (2002). Keynote address at the $8^{\text {th }}$ Annual conference of the Agricultural Extension Society of Nigeria held in Benin City, 16 - 19 September, In Olowu T. A. (Ed). Proceedings of the Agricultural Extension Society of Nigeria. 
[49] Iremiren, G.O. (1992). Our Bread is No More Daily. Inaugural Lecture Delivered at The Federal University of Technology, Akure, Nigeria, April 17, 1992.

[50] Jacob, O.I. (2013). Food Insecurity in Nigeria: Way Forward. Department of Economics University of Jos, Plateau State, Nigeria. International Multi disciplinay Journal, Ethiopia. Vol. 7 (4). Serial No. 31, September, 2013. Pp. 26-35.

[51] Jrad, S., Nahas, B., and Baghasa, H. (2010). Food Security Models. Policy Brief No. 33. Ministry of Agriculture and Agrarian Reform, National Agricultural Policy Center, Syrian Arabic Republic, August 2010. Pp. 1-32.

[52] Jayne, T.S., Zulu, B., Mather, D., Mghenyi, E., Chirwa, E. and Tschirley, D. (2005a). Maize Marketing and Trade Policy in a Pro- poor Agricultural Growth Strategy: Insights from Household Surveys in Eastern and Southern Africa. Paper Prepared for Conference "Toward improved Maize Marketing and Trade Policies in the Southern Africa Region" Sponsored by FANRPAN/ Rocket feller Foundation, Pretoria, South Africa, June 21-22. 2005.

[53] Kirwan, J., and Maye, D. (2013). Food Security Framings within the UK and The Intergration of Local Food Systems. Journal of Rural Studies. 29, 91-100.

[54] Kothari, C.R. (2004). Research Methodology: Methods and Techniques. (2 ${ }^{\text {nd }}$ Edition). New Age International Publishers.

[55] Makombe, T., Lewin, P. and Fisher, M. (2010). The Determinants of Food Insecurity in Rural Malawi: Implications for Agricultural Policy. IFPRI Policy.

[56] Mano, R., Isaacson, B. and Dardel, P. (2003). Identifying the Policy Determinants of Food Security Responses and Recovery in SADC Region: A Case of the 2002 Food Emergency Food Agriculture and Natural Resource Network Policy Paper.

[57] Maharjan, K.L., and Chhetri, A.K. (2006). Household Food Security in Rural Areas of Nepal: Relationship between socio-economic characteristics and food security status. Paper Presented at the International Association of Agricultural Economists' Conference, Gold Coast. Australia. August 12-26.

[58] Mutisya, M., Kandala, N., Ngware, M.W., and Kabiru, C.W. (2015). Household Food (in) Security and Nutritional Status of Urban Poor Children Aged 6 to 23 months in Kenya. BMC Public Health. 15(1):1.

[59] Ndaghu, A.A., Maurice, D.C., and Zubairu, E. (2009). Adoption of the New Rice for Africa (NERICA) Rice Variety among Small Scale Farmers in Taraba State. Nigerian Journal of Tropical Agriculture 11:259-265.

[60] Okon, U.E., Frank, N.N., Etowa, E.B., and Nkeme, K.K. (2017). Household Level Food Security States and it's determinants among rural farmers in Akwa Ibom State, Nigeria. Agricultural Science Journal Vol.7 (10): 297-303. October, 2017.

[61] Okwoche, V.A., Asogwa, B.C., Obinne, P.C. (2012). Evaluation of Agricultural Credit Utilization by Cooperative Farmers in Benue State of Nigeria. European Journal of Economics, Finance and Administrative Sciences. April 2012.

[62] Olayemi, J. K. (1998): The Nigerian Food Equation towards a Dynamic Equilibrium, University of Ibadan Inaugural Lecture. No. 167.

[63] Oluwatayo, I.B. (2012). Gender Considerations in Decision Making in Rural Nigeria. Implications on Households Food Security in Ekiti State. Multi disciplinary Journal of Empirical Research. 2 (1). Pp. 21-30.

[64] Oluyole, K.A., Oni, O.A., Omonona, B.T., and Adenegan, K.O. (2009). Food Security among Cocoa Farming Households of Ondo State, Nigeria. Journal of Agricultural and Biological Science. Vol.4. No.5,Pp. 7-13.

[65] Omonona, B.T., and Agoi, G.A. (2007). An Analysis of Food Security Situation Among Nigeria Households: Evidence from Lagos State, Nigeria. Journal of Central European Agriculture, Vol. 8, No.3 Pp. 397-406. 
[66] Omonona, B., Agoi, T. and Adetokunbo, G. (2007). An Analysis of Food Security Situation among Nigerian Urban Households: Evidence from Lagos State, Nigeria. Journal of Central of European Agriculture. 8 (3), 399-406.

[67] Omotesho, O.A., Adewumi, M.O., Muhammad- Lawal, A., and Ayinde, O.E. (2006). Determinants of Food Security among the Rural Farming Households of Kwara State. Nigeria. African Journal of General Agriculture, 2(1): 7-15.

[68] Oni, O.A., Salman, K.K., and Idowu, B.O. (2011). Social Capital Dimensions And Food Security among Farming Households in Ogun State, Nigeria. Journal of American Science 7(8): 776-783.

[69] Oriola, E.O. (2009). Irrigation Agriculture. An Option for Achieving the Millenium Development Goals (MDGs) in Nigeria. Journal of Geography and Regional Planning 2(7). Pp. 176-181.

[70] Oyebanjo, O., Ambali, O. I., and Akerele, E.O. (2013). Determinants of Food Security Status and Incidence of Food Insecurity among Rural Farming Households in Ijebu Division of Ogun State, Nigeria. J. Agric. Sci. and Env., Vol. 13, pp.92 -100.

[71] Pinstrup - Anderson, P. (2009). Food Security: Definition and Measurement. Springer Sciences Business Media BBV and International Society of Plant Pathology.

[72] Robert, A., James, O.M., and Thomas, T. (2013). Determinants of Household Food Security in the Sekyere - Afram Plains District of Ghana. Proceedings of the International Inter disciplinary Conference Azores, Portugal, 24 - 26 April.

[73] Rose, D., Gunderson, C., and Oliveira, V. (1998). Socio- economic Determinants of Food Insecurity in the United States. Department of Agriculture, Economic Research Service, NY. United States.

[74] Shala, A., and Stacey, E. (2001). United States Department of Agriculture: Economic Research Service. Food Security Assessment, Regional Overview Information Bulletin. United Nations Integrated Regional Information Network (2002): Food crises Aggravates spread of HIV.

[75] Shehu, A.A., Maurice, D.C., Yohanna, I., and Stephen, F.S. (2012). Analysis of Resource - use Efficiency in Rice Production for Food Security among Farmers in Yola South Local Government Area of Adamawa State, Nigeria. Savannah Journal of Agriculture. 7 (1). Pp. $104-109$.

[76] Smith, J. (2007). Food Security in Sudan: Darfur- overview. Sudan. June 2007. UNICEF. http://www.unicef.org/infobycountry/sudan-darfuroverview.html.

[77] Tewe, O.O. (1997). Sustainability and Development: Paradigms from Nigeria's Livestock Industry. Inaugural Lecture Delivered at the University of Ibadan, Ibadan, October 9, 1997.Pp 1-84.

[78] Valdes, A., Foster, W., Anriquez, G., Azzari, C., Covarrubias, K., Davis, B., Digiuseppe, S., Essam, T., Hertz, T., Paula de la, A.O., Quinones, E., Stamoulis, K., Winters, P., and Zezza, A. (2010). A Profile of the Rural Poor. A Background Paper for IFAD Rural Poverty Report. IFAD. Rome. http://www.ifad.org/rural/rpr2010/background/2.pdf.

[79] World Bank (2008). The Growth Report: Strategies for Sustained Growth and Inclusive Development. Washington, DC.

[80] World Bank (2000). World Development Indicators 2000. World Development Indicators. Washington, DC. (C) World Bank. https://openknowledge.worldbank.org/handle/ 10986/13828 License: CC by 3.0 IGO".

[81] World Bank (1986). Poverty and Hunger: Issues and Options for Food Security in Developing Countries. Washington DC.

[82] Yusuf, S.A., Balogun, O.L., and Falegbe, O.E. (2015). Effect of Urban Household Farming on Food Security Status in Ibadan Metropolis Oyo State. Nigeria. Agricultural Sciences. 60 (1): 6175.

[83] Zubairu, E.A., and Maurice, D.C. (2014). Analysis of Household Food Insecurity among Food Crop Farmers in Ardo-Kola Local Government Area of Taraba State, Nigeria. Taraba Journal of Agricultural Research, 2 (2): 20-25.

\footnotetext{
*Corresponding author.

E-mail address: abdualiyu14@ ymail.com
} 